\title{
Surprised to see beggars
}

\section{Luther Saroy}

In the course of completing my learning assignment in Bandung, I was very surprised to see beggars. They were panhandling right up to the classrooms where we studied. In Papua we were not yet familiar with beggars; we were used to an orderly life. At that time, in 1963, many civil servants were sent to Java to study the Indonesian governance system. I had been sent to Bandung as part of Mr Boekorsjom's group.

The beggars were eventually driven away, and the gates shut. We lived in dormitories on Dago Hill, in a former hotel from the Dutch-era. In the streets there we were always followed by beggars too. When we went to the zoo we again ran into beggars. They just kept on begging. I thought then, oh, this was just the way it was. But I felt sorry for them.

The leader of Papua at the time was Governor Eliezer Jan Bonay, who had also been the first governor of the province of Irian Barat (for not quite a year, in 1963-1964). In an official telegram, Pak Bonay had ordered almost all of the civil servants in Serui to go to Bandung. My name was in the telegram, but because it was dirty, it was illegible. Pak Imbiri went back to ask in Hollandia, whose name was that last one? Then Pak Bonay replied: 'That's my boy'. And he called out all the names. Pak Imbiri came and told me: 'Get ready to leave!'

The Oranje - which was the governor's ship, whose name had been changed to Dwiwarna - was docked and ready at the Serui pier. We departed for Biak and headed onward to Jakarta. At the time there were feelings of hatred toward the Indonesian government. My teacher, who was Dutch, had told us: 'Later when the Indonesian government comes in it will bring in all sorts of diseases. Real diseases, and also, diseases like stealing and lying.' I was God-fearing. Concerns arose in my heart: 'Well, if I go there later I'll be ruined'. But to adapt to the government system in Indonesia, I had to go! I took a suitcase containing all of my clothes. 
The money we brought amounted to IBRP 100 (a hundred Irian Barat rupiah), which was worth IDR 100,000 (a hundred thousand Indonesian rupiah) when it was exchanged. Mr. Imbiri and I exchanged it over there (Java).

We studied in Bandung for six months. Everyone who worked in government, all of us had to leave to study the Indonesian governance system. We and the group from Yapen Waropen first met with the Minister of Home Affairs Epi Kandama. Pak Bonay himself had said: 'Ah, so that you make an appearance before the minister of regional autonomy'. When that was done we got civil defense uniforms for a month-long military training. After that, we spent the following months learning the governance system, Pancasila (the five principles of Indonesian national philosophy), Garis-garis Besar Haluan Negara (GBHN, Broad Outlines of State Policy) and state administration.

While in Bandung we heard that a cholera epidemic was striking many people in Yapen-Waropen. Mr. Imbiri said to me: 'Those of us who have families are allowed to go home, but you stay because you're still single'. I said: 'That can't be. We came here together, so if we go home, all of us should go home!' Brigadier general Sucipto came and said: 'Brothers, there's no need to worry, the health team has been sent and their people are already there. So don't be afraid, there's no problem, it will be taken care of.'

In December, after completing our education, we returned home. I had asked to stay there to pursue my education further. But Governor Bonay said: 'No, you come home! Later you can join the second class at the Academi Pemerintahan Dalam Negeri (APDN, Academy for Domestic Governance) in Malang.' But after I returned to Papua he was dismissed as governor. This was because Bonay strongly wished his country to be independent. If I am not mistaken, there was one party that requested that, during the United Nations Temporary Executive Authority (UNTEA) period, a direct election be held for Papua to secede from Indonesia. But there were people from the Indonesian side who urged that it was imperative to sign a statement relinquishing the right to self determination: 'If you will not sign this statement, get out of here and look for another land to live in!' Well, that was very hard! In Jayapura some people were shot. At first, people thought that Indonesia would improve things, although that was not the case. Many Papuans fled to Papua New Guinea (PNG), including students from Cendrawasih 
University (Uncen). They could not return here in 1969, or in 1970 either. They were forced to become citizens there. All of them, including Clemens Roenaweri and Wim Zonggonao, kept on living there.

\section{GOING TO OSIBA}

To be selected to continue their education to OSIBA, students had to meet several requirements, among others, being the son of a tribal chief or korano (village head) or ondoafi (adat leader). They had to be in excellent physical and mental health. Their report card scores must be good and their relationships with teachers and fellow friends also had to be good. And they had to pass an entrance examination. The school belonged to the government, in this case, the Dienst van Binnenlandse Zaken (Department of Home Affairs), so all the costs were borne by the government. Every major holiday or vacation, the students usually returned home by plane. Those accepted into OSIBA were usually graduates of a Jongens Vervolgschool (JVVS, follow-up school for boys), except those from big cities like Hollandia, who were graduates of the sixth grade of an Algemene Lagere School (ALS, General Elementary School).

Candidates were nominated by the school principals. Because the school principals knew the attitudes and character of the children. Since in the future the student would have to serve as a capable administrator, he had to be well disciplined. So, for example, if the child was lazy, or not diligent enough, then he would be sure not to be accepted, even if his scores were good. Most, if they were from a JVVS, could be accepted directly. It was different with those from an ALS, since most of them lived in the city, where the influences of the urban environment were not so good. So if they were from a JVVS it was not that hard to get in, because, as in my own case, the director deemed I would be good.

At that time I wanted to get into the junior high school that was the first to open in Manokwari. But it turned out that my final examination scores were great for OSIBA. Oh, at first I declined applying to enter OSIBA, but the director said that my grades were high. So, finally, I was forced to go along with it. I was there together with my friends Amos Yap and Jos Marey. We have continued to stay in touch up until today. Oh, it was only later, when we were already here in Class B, that Jos Marey 
came in with his friend Bernard Joku. Joku later fled to PNG and died there in 1993 or 1994, then his corpse was sent to be buried here.

OSIBA was the successor of the school formerly known as the BOS or the Administrative Training School. The men who went to BOS for a three-year education programme were then placed as candidaat hulp bestuursassistent (CHBA or candidate assistant administrative officer ). Because in those days, none of the indigenous civil servants had mastered the Dutch language properly yet. They managed only with an intermediary language, Malay. It was not yet called Indonesian.

The five-year course of education was only called OSIBA from 1951 onward. Actually, it was four years plus one year of practice, for a total of five years. But from the time my friends and I entered the school in 1958, the one-year practice was eliminated, so it became just four years. Thus, those of us from the JVVS as well as from the 6th grade of ALS could be accepted through an entrance exam. At OSIBA they had to speak Dutch. So at school, no one was allowed to speak Malay. If someone was caught speaking Malay at school, he was removed from OSIBA. Because when I was still at JVVS, a circular letter from the governor of Netherlands New Guinea was sent to everyJVVS and ALS, announcing that Dutch was the working language both inside and outside the schools.

\section{THE LAST CLASS}

So, anyone who entered this school, namely OSIBA, had to obey the rules or regulations in the dorms as well because if they did not comply they would be reprimanded up to three times, and then immediately expelled. That was firm, it was disciplined! And after two years we had to pass exams. So the value of the diploma was equivalent to that of a four-year high school (PMS).

I was in the last class, one class behind Joel Boray's. Actually, I was going to enter OSIBA in the same class as Pak Boray, as I had taken the first entrance exam and passed. But at that time the assistant administrator in Napan, Mr. Supit (a Manadonese), said: 'Wait, when the next telegram comes I'll send you off.' The plan was to depart by Beaver (water plane). I waited and waited until December; it appeared it was not to be. So I wrote a letter to the director in Miei, Mr. Wandamen. Well, as soon 
as he received my letter, he replied: 'Come quickly! I will accept you in December' Yes, in December I boarded the ship, the Ms Cycloop.

I arrived there (in Miei), and was welcomed. Then, well, instead of sending me to OSIBA he asked me to teach first-and second-graders at the JVVS. Including third graders as well - my friends. So I had to write everything down, if they did not come to class. 'Ah, you take this, write it down, later your friends can copy it. I know you already know everything.'

Finally another exam to enter OSIBA was held, but I refused to do it. No, I would go to the PMS. I had graduated the year before, but had not been sent. 'Oh no, now sit the exam here.' The exam was supervised by the HPB and his friends. Then we were done and went home, returning there for the holidays. Then HPB Lapré from Wasior came and said: 'You, go to be tested in Waren.' After the testing, I went home and the results were released. Now the names of those tested would be sent to OSIBA. As it happened, Saroy and Amos Yap had passed and could go. I did not want to go, but Amos did not push me. He just waited and was ready to go. If I did not leave, he would not leave either. And we would all receive two certificates. I would get a certificate for PMS Manokwari, if I refused to go into OSIBA. Indeed I did refuse, but my parents pressed me. 'You just go to OSIBA. After all, every vacation you'll come by plane!' I said: 'True, I'd go by plane, but if it crashed, I'd die at one'. Ha, ha, ha. They said: 'Leave that to God. That's in God's power.' Well, but at school I had the director watching my steps, and he said: 'Hey, you could become an important person later on!'

So, I entered OSIBA at a very young age. For me, the most interesting topic, at that time and up to now, was sports. I chose this topic because of the Latin saying: 'In a healthy body there is a healthy mind' (Mens sana in corpore sano). So for the final exam at OSIBA, I chose volley ball and football because one can enjoy these games anywhere. A volleyball court does not take up much space. The same goes for fields for football, as my second choice. And both types of sport are popular among people in some parts of the world. For example, nowadays in Europe. And as a civil servant you had to introduce these two sports to the people. 


\section{NOT ALLOWED TO STAY AT THE GUEST HOUSE}

After graduating OSIBA, I set foot in Serui on 1 September 1962, and immediately met with HPB Meijer. He took me and introduced me to all the employees. After that he asked: 'Where are your things now?' I answered: 'At the pasanggrahan (guest house)'. He said: 'Oh no, no, no! You should go to the police barracks.' I immediately asked: 'Ah, who says so?' 'Otherwise, at the end of the month, your salary will be finished'. I said that could not be. There was a hotel expense allocation in the budget - could I not use it? 'No, that's the theory, but in practice it's different'. Well, I was a bit taken aback that I had talked so much, then I thought to myself: yesterday, with the resident, I got along just fine. And I still remembered the advice of my teacher at OSIBA, Mr. Wieringa, who said: 'When you practice in the community, you must uphold your supervisor highly. Don't put him down, that is not permitted. You must listen, obey and submit to him. Even if he is awful, you must be obedient because he is your superior.'

Yes, when we went to school at OSIBA we learned that the administration was the same everywhere. In the administration in Ransiki, Serui the calculation remained the same, namely, 12 percent. So, if, for example, I did not have my own employee housing, I was entitled to receive 12 percent of the allocation for hotel expenses to enable me to stay at a hotel or guest house. But the HPB said: 'That is what you learned at school, but now this is practice. The rule does not apply in practice. Previously, Mr. Somboek stayed at the police barracks.' Yes, I was forced to give up; I had to go live in the police barracks. In the HPB's administration, there were no funds for that. The resident had not yet provided them to HPB. Perhaps the resident was still holding the funds, so the rule was not yet applicable here.

Yes, it was the HPB's duty to find a place for me. But because at the time there were no funds available for the guest house, I was ordered to occupy the police barracks. So that was quite an experience. My friend, Mr. Markus Yom, who is now retired, had the same experience too. He came with his wife, but because there was no house, he lived with the villagers. I thought about it. I felt I should fight back. But ... well, that was no way to start off, I was still new here.

Yes, that was the authority of the HPB. Since I was new, I had no experience. So the day before I had not discussed it with the resident 
in Biak. I did not know, anyhow, did I? Only once I got there did I find out the situation was like this. What could I do, I had to accept it. I was forced to go live in the police barracks.

As for Pak Yom, he was a senior, he had already been in government service for a long time. He was from almost the same class as Pak Florenz Imbiri. But Pak Florenz's grades in school at OSIBA were outstanding. So he was quick to rise to a higher rank, meaning that he was already a district head earlier on. Now, after the New York Agreement, all the former OSIBA people were summoned: who might be capable of replacing HPB Meijer? Actually Pak Imbiri was appointed to serve as HPB in Sarmi, but because Mansawan was in Sarmi, Mansawan became the HPB there. And Pak Imbiri was directly appointed as HPB in Serui, replacing Meijer. So he replaced Meijer as the HPB and at the same time served as the chairman of the regional council of Yapen-Waropen. HPB Meijer thought that Yom might not be capable, because he was not that fluent in his mastery of Dutch. So finally I was summoned to come in. And Mr. Meijer said to me: 'You will replace Mr. Winter, because he is going to return home to the Netherlands.' I said: 'Oh my, I am fresh out of school, I am not capable.' He said: 'Oh no, you better think about it first. Go take a walk and think about it carefully, then you come back to let me know.' I mulled over it, then Mr. Florenz Imbiri said: 'Just accept!' But it was very tough for me; I was still new, I was still green. So I went walking and thought it over.

Then HPB Meijer called in Bouwman, the administrative officer. Previously, the position of administratief ambtenaar was held by a person holding a title of drs or doctorandus (a Dutch title, today's equivalent of a master's degree). But perhaps most Dutch people did not want to use the title - one had to complete the degree first. So not until they actually received the title of 'doctorandus' would a title be used. So Mr. Bouwman was summoned. 'Please hand your bicycle over to Mr. Saroy, because later I'll give mine to Imbiri'. At the same time, the Fongers bicycle was also transferred. In Serui back then people did not use cars like they do today. The HPB always rode a bicycle, even though he held a law degree. That was the advantage of the Dutch! They humbled themselves! Mr Meijer said: 'I am pleased with you, so you should become secretary of the council'. Imbiri said to me: 'Accept!' Okay, I accepted.

All of this was in the framework of Papuanization. Before, in the Dutch period, there was the Peraturan Gaji Pegawai Negeri (PGPN, 
Regulation on Civil Servant Salaries). Later, only in the Indonesian period, came the Peraturan Gaji Pegawai Sementara (PGPS, Regulation on Temporary Worker Wages). Formerly, we used guilders, Nieuw-Guinea Gulden. Guiders were used in the Netherlands. But later, the NieuwGuinea Gulden was Indonesianized into the Irian Barat Rupiah, or IBRP. According to the congress, this was the currency that was going to be used once Papuans became independent. Actually I had some, but it disappeared along with my wallet when I left for Serui. Someone took it. The amount was in IBRP.

\section{PLACING HOPE IN HABIBIE}

Out of the lessons given in school, those I still remember to this day are the ones in constitutional law, taught by Mr. Sarolea. He was a Dutchman, but he was not too tall, almost the same height as me. He was fat. He was great when he taught! He explained how the NieuwGuinea Raad (New Guinea Council) was established and its work system. How Dutch New Guinea was going to be just like the Dutch Antilles and Suriname. It had all been decided, that it would be given the right to be autonomous. Each time he finished giving a lesson at school and went home, I just had to tag along with him to Hollandia-Haven, now the port of Jayapura. We talked constantly, and he asked me: 'So, do you find my lessons interesting?' I said: 'They're excellent!' We talked in Dutch. 'So, supposing that later you become independent, you won't be angry with the Dutch?' I replied: 'Oh no, we could never be angry with the Dutch, because it's the Dutch who have made everything good here'. He said: 'But now Indonesia wants to come here!' 'Oh, that's impossible, impossible', is what I said. Later, when I was at my new post, everything happened just as we had once discussed.

It was my educational foundation that enabled me to master the Indonesian governance system. For example now, take the DPR (Provincial Council of People's Representatives), MPR (National People's Consultative Assembly) and DPA (Council of State) in Jakarta. Anyway, it was all modeled after Montesquieu, right? Those were his three criteria. If I look at the administration today, I think that Indonesia is only promising what is called autonomy. Autonomy was granted from the beginning, in Soekarno's time, but it has never been implemented so as 
to give absolute rights to the Papuan people. You can see it plainly in the government offices, where it is not Papuans who play the important roles. Instead people from elsewhere are the ones who occupy those positions.

$\mathrm{Ah}$, it is not autonomy anymore. It is no longer true. Up to the last moment they are just shocked they cannot stem the determination of the Papuan people to demand their rights. The central government in Jakarta refuses to admit its mistakes. Recently the Team of 100 people representing Papua went before Habibie. Habibie ordered them to go home, to consider it carefully first. To do their homework. Habibie knew that when this region entered the Republic of Indonesia, it did not go through the MPR. It was not in any MPR resolution. It was not ratified in the State Gazette of the Indonesian Republic. Ah, Papuans have the right to take action. Back then, the UN was wrong.

The UN was wrong because it did not send in its troops to oversee the implementation of the Act of Free Choice in all the districts, to ensure every Papuan was free to vote: "one man, one vote". Now according to Ortiz Sanz from Bolivia, South America, the implementation of the Act of Free Choice was in fact done at gunpoint. This was not legal. So the Act of Free Choice was invalid. But the recognition of the results of the Act of Free Choice was already out there. In my opinion, Habibie could have asked the Team of 100 to form a team to investigate the implementation of the Act of Free Choice.

The Papuan people had faith in Habibie. People here thought, Habibie was educated in Germany so he was sure to know what democracy was. And now it also turns out that Amin Rais, chairman of the MPR, is a professor with a doctoral degree. Why then, when Papuans went to talk to him, did he say: 'Go see Gus Dur'? It was as if Amin were washing his hands of it. He knew that the entry of this region into the Republic of Indonesia did not go through the MPR, but only through a presidential decree. So he maintained that the MPR should do nothing. Because maybe he thought: 'It came in before without going through me (that is, not by going through the MPR), so why ask me for my permission now?'

\section{FOOD CRISIS}

In the first year I worked as a civil servant there were Mr. Meijer and Mr. Bouwman. It was August 1962, and the New York Agreement already 
existed. Its contents had been secretly conveyed to the resident and the HPB. Therefore, they were getting ready to go home. So their positions had to be transferred to Papuans. At that time Imbiri was going to occupy the position of HPB and I was told to replace Mr. Winter. We were in Serui at the time.

During the UNTEA period a lot of Indonesians had already come. Because they knew, they said, that this too was a former territory of the Dutch East Indies in the past.

So they had come in on the sly. When KPM ships came from Singapore carrying goods, lots of Indonesians also came along with them. They were sent as volunteers for development. Papuans who had been in Indonesia for a long time came too. And they also brought their families from there.

Before the UNTEA left, the Indonesian National Army (TNI) were already here, not wearing uniforms, but dressed like ordinary people. They came and entered shops carrying army bags. They bought from the shops till the shops ran out. At that time we did not know whether the money they were using was counterfeit currency or not. Basically the shop owners here just accepted it; what was important is that it was money. The Dutch-period Esquier store had been taken over by Albert Numberi. It was a Dutch store that carried woolen clothing. After a long while all the goods ran out. The shops were empty of canned foods. Things were hard. Papuans wanted to demonstrate to demand that the vote should be held soon, for Papuans to stand on their own. Finally Indonesia pushed the UNTEA to shorten the time! Oh, times were very hard!

But in Serui I kept the situation under control. The people who ran the Nieuw-Guinea Import \& Export Maatschappij (NIGIMIJ) depot had also gone home and handed it over to the logistics depot. It contained stocks of rice, sugar and milk. But the term NIGIMIJ continued to be used. The currency in use was still the guilder, then it was replaced by the IBRP. The warehouse was filled with goods. In Manokwari and Biak there was a food crisis. Inevitably, a telegram arrived asking for help, for rice to be sent if there was still any left. Pak Imbiri called me: 'How about it?' I said: 'For Biak, we'll help, because they're neighbours. But as for Manokwari, we can't. If we run out, they won't help us, except for Biak.' He listened to me. Then we sent aid to Biak.

Biak was a neighbour to Yapen since it was adjacent to it. That is why food aid had to be provided. But Manokwari was located far away, 
so we could not be certain it would help us quickly if we ran into trouble with food. Whereas Biak could because of its proximity. We could run over there by boat. Finally, Pak Imbiri accepted: 'OK, arrange it!' As soon as the Etna Bay ship came in, we sent help to Biak. Manokwari, we did not oblige, but only answered their telegram: 'Yes, we are also going into crisis.'

Ah, that was in the time leading up to the outbreak of the Gerakan 30 September (G30S, 30th of September Movement) in 1965 in Jakarta. So I managed to survive. At that point Imbiri did not know the inventory of what was there either, so I had to report to him that there was butter, there was milk. According to the provisions of the time, if a can was damaged, all the contents in the cardboard box the can was in were declared damaged as well. So I used that to help the employees who worked there.

Rice was always stored in double sacks. If the outer sack was torn and rats had already got in and eaten some of the rice, then that rice sack was declared a reject. I gave that rice to the employees. Blue Band margarine and milk that was still good I brought and gave to Imbiri at home. He asked: 'Oh, where did you get this from?' I pointed to my block of notes and said: 'Please read this, sir.' Those were the rules. So I acted on them like that for the welfare of the employees who worked there so they could work calmly. So we managed all of these circumstances properly. As civil servants, we had to gauge the future situation and the current situation, how we could manage them. Often, people could go wild, just because of hunger.

\section{ALL THE GOODS ARE BOUGHT UP}

Indications of the G30S began to be felt as everywhere, all the goods were bought up. So people from outside of Papua were coming here to get goods from here to help out over there, so the goods in the shops ran out very rapidly. Yes, they took all the goods. Even the fine doors and windows from the Dutch period were removed and taken away. Even broken bicycles, which we had told them, oh, let them be repaired before you buy them. The soldiers came with their bags and asked: 'How much do you want to sell this for?' Oh-oh, alright then, we had no choice! If it did not happen today, he would come back again tomorrow. Alas, I 
thought: 'Ah, so, is this it ...?' I recalled what my teacher had told me: 'Later, real diseases and other diseases will be brought here'. It was becoming true, the army alone was like that!

I returned home from Java in December 1963 together with Imbiri and other friends. The others were subordinates, so all that remained was to give them their orders. After Meijer left, I held a double post. Imbiri replaced him as chairman of the Streekraad (Regional Council), with me as his secretary. Records often came in. As for the council, when it had funds, there was no treasurer to store them. But there was a safe I had to guard. So aside from being the secretary, I was also the treasurer. So I was the one who did all the bookkeeping. Now Serui is built up, but in that time, the council was a pioneer. Serui was developed with council funds at that time. Take cocoa fermentation, for example. It was the council that managed and shipped the cocoa with the KPM to Singapore. The money came in guilders at the Nederlandse Handel Maatschappij (NHM) Bank, which was later replaced by the Bank Nasional Indonesia (BNI).

The chairman of the cocoa fermentation foundation was $\mathrm{Mr}$ Waimury, who was a native of Serui. He was related to Theo Waimury who worked at an Indonesian embassy abroad. The cocoa sales proceeds were sent through the Indonesian bank in Waimury's name--not in my name as the secretary, because that was their right. If I had been chairman of the foundation, the money would surely have been sent back in my name. And I could have saved that money for development. Yet Waimury acted as if it were his own money, even though it belonged to the cocoa farmers in Yapen-Waropen. However, I could say nothing, because he was an elder, and the money was sent in his name. Later he was sent from Serui to Nabire to serve as the kepala pemerintah setempat (KPS, head of local government) or HPB. And I too was transferred, to Bokondini in the interior.

\section{RICE MIXED WITH SALT}

When Mr. Meijer was still there, I worked under an old administrator named Leasiwal. He was an Indonesian who came from Ambon. He was quite old. He often took me to the penitentiary, where he taught me how to provide food to the inmates. So I paid attention. He instructed 
me to add salt and chili peppers to plain rice for them to eat. I said to him: 'Gosh, Bapak, what about this? Now that the Dutch have left, in the Indonesian period we'll have to follow Pancasila.' He said: 'Just so you know, boy, no rules have been set by the Indonesians yet'. I said: 'Yes, but what about this. I see that this food is so bad.' He said: 'These are people who have committed crimes. We do that so they will repent.' I said: 'Bapak, later, over time, these people could revolt'. He said: 'As I have let you know, this is according to the rules. If you do not follow them, I won't have you come here again.' I said: 'Ah, I would be happy not to come here again. Because I have humanitarian feelings. Unfortunately, they are here because they have made mistakes. But if they had not made a mistake, surely they would be the same as us. Poor things!' He replied: 'Oh, you can't think about it like that. We have to teach these people a lesson so they repent!'

This was hard, because I found myself between the two sides. Which one would I choose? So I admonished: 'The Dutch have left, so now let's apply Pancasila.' He said: 'There are no provisions for that yet. Any government would do the same.' Then he added: 'Alright then, next time you won't come here again'. In the end I never did go back again. I only had to take charge of the sanitation department.

Mr. Bouwman had given me his bicycle. I had to go inspect the gutters. Then I went home and made a report: 'Bapak, the road to the hospital is dirty, even though sick people are being treated there'. He took notes, typed them up, and submitted them to Mr. Imbiri as the HPB. He gathered all information for later deliberation by the board. So I had to invite the board to hold a session. Well, I could not sleep and worked through to the following morning until almost noon, but felt just as I normally did. At the time I was still single, I had no life mate. So I only thought about my job. I inspected the cleanliness and beauty of the city and reported on it to Mr. Leisiwal. I surveyed the market, controlling the vegetable sale prices and market fees.

I went to the Department of Public Works to look at the goods stored in the warehouses. We supervised it. When there was a job to be done, we had to call the HPB, or KPS. At that point the term KPS was already in use. As soon as we entered the transitional period, the name HPB was crossed out and the name KPS was used instead. 


\section{HANDING OVER SECRET TAPES}

As it is commonly understood, on 15 August 1962 the New York Agreement was signed at the United Nations headquarters; and on 7 April 1962 Indonesia agreed to the Bunker Plan (with Ellsworth Bunker, an American UN diplomat appointed as mediator): for the transfer of authority to take place after six months under temporary administration by the UNTEA, and The Act of Free Choice after six months under Indonesian administration. On 17 August 1962 President Soekarno only agreed to the Papuan people's right to self determination on an internal basis.

On 1 October 1962 the Netherlands handed over its job to the UNTEA, which was headed by Dr. Djalal Abdoh. In November 1963 the Indonesian army forced 11 Papuan leaders to sign a document stating that they relinquished the right to self determination. And in December came the arrest and persecution of Papuans who had stirred up a demonstration, declaring their desire for the election to be held under the protection of the UNTEA, that is, the UN. Indonesia entered directly, stealing its way in, even though the authority of the UN still held until 1 May 1963.

In Sukarnopura (present day Jayapura) there were people who were arrested and have never been found again to this day. It is said that they were brought to Jakarta, then disappeared there. Among them were former members of the Nieuw-Guinea Raad. They were eliminated before the Dewan Musyawarah Pemilihan (DMP, Election Consultative Council) for the Act of Free Choice was formed. Those men were sought out; where exactly had they been taken? So that was the way the Indonesians worked.

They were not taken at the demonstration. They had gone home, but were already being followed! Because photos had been taken, then they were tracked down. Intelligence had already checked out their homes, then picked them up saying: 'You have been summoned about this matter.' It happened to our friend, Penehas Torey. Up to now he has remained missing, no one knows where he went. He too was a graduate of APDN Malang, together with Faidiban. He finished his studies there, married a Javanese woman, and lived in Dok V. He was arrested at the time. He had attended the South Pacific Conference. And he was a former member of the Nieuw-Guinea Raad, still very young, but eliminated just like that! 
As for Pak Boekorsjom he was actually detained in Manokwari during the Free Papua Movement (OPM) event in 1965. At the time he was serving as KPS in Wasior, then his relative, a nephew of Amos Yap's came over there. They were arrested in Wasior and brought to Manokwari. They were brought in together with several others, including Faidiban. Only later, after Soeharto granted them amnesty and abolition, were they set free. They received a public pardon. Yet, as if this had not been granted, later, on the job, they would be branded as former political prisoners. Just now, at the Kongres Pelurusan Sejarah, ${ }^{1}$ those who are former political detainees were included on the panel. I was not on the panel, but was there only as a bystander.

I was not detained; we were just part of the underground movement. So each time an issue came up, I recorded it on cassette. Once my brother-in-law came from Manokwari to Serui. I gathered the students of SGB (a school for village teachers or Lower Level Teachers School) and they sang at my house and I recorded it on tape. I brought the cassettes when I moved to the interior. One day, Ortiz Sanz came to visit Bokondini. I do not know how it happened, but it was the work of the Spirit of God. Ortiz Sanz and a whole entourage of bupati came to eat at my house. At one point, Ortiz Sanz wanted to go to the toilet, but I already knew what his real intention was. It was at that moment that I handed the tapes over to him.

Ortiz Sanz could not do anything because he had not come with UN troops. So Papuans could not do anything either. UN troops should have been placed in each district to protect rights to a "one man, one vote" election. But because he came without UN troops, he too was overwhelmed in the end. I surrendered the tapes to him and he took them. I do not know what happened next. Perhaps it was only to find out information. Perhaps he brought them there, or perhaps he played the tapes and then threw them away. I trusted him because I thought: $\mathrm{He}$ was someone from outside, so he was sure to understand that what we conveyed were the aspirations of the Papuan people. Yet I could also be in danger. In fact I was also at the tip of a spear, but I had courage. And actually, I had also sent some of the tapes to PNG.

\footnotetext{
1 Saroy refers to the second Papuan People's Congress of May-June 2000 that was seen as a meeting to set the historical record straight.
} 
From Serui I was transferred to Bokondini to replace Bapak Karma. At the time, Bapak Karma went down to Sukarnopura to serve as the wakil bupati of Jayapura. The bupati was Anwar Ilwan. Before that, Onim was the bupati of Jayapura, but he was transferred to Fakfak as the bupati there to replace Mr. Mampioper, because Mr. Mampioper had been appointed as the administrative bupati of the Jayawijaya Mountains regency in Wamena. So at that time Arnold Mampioper was the bupati.

In 1963 Pak Mampioper, Pak Boekorsjom and all of us were in Bandung. That time I had joined a group of older people. During the Act of Free Choice, students of Cendrawasih University (Uncen) held a demonstration in Sukarnopura. I was still in the interior then, so I sent my wife and child to go down to Sukarnopura ahead. I said: 'I'll wait here first, because it's so easy for me to get carried away by emotions. If I went down together with you, I would definitely take part in the event there. Then things could become dangerous for me. You go first, and I'll follow behind later on.' Then, when Pak Mampioper came to Wamena, he stopped in Bokondini together with Ortiz Sanz. And he told me: 'Mr. Ortiz Sanz is going down there, so you go too'.

I was concerned because some people were already being arrested and detained at Ifar Gunung. One of them was a friend of mine, who had shared a desk with me in Fakfak - at the time when Mampioper was bupati in Fakfak. This friend came from Sentani and his name was Soleiman Nukuboy. At the time we held the same rank as assistant administrator candidates (CBA). But it happened that in Fakfak he participated in underground activities as secretary to the OPM. The army kept looking for him, and when we were attending the SELATPUDA in Hamadi in 1967, he was arrested and taken to Ifar Gunung. He died during military detention in Ifar Gunung in 1968.

My family headed out first, and I was to follow later. So our things, like the chairs and sewing machine also had to be brought there along with some of our baggage. The things had already been uploaded to the airplane. I was going to travel on a MAF plane. People were sitting around the aircraft. The pilot, Pablo, an American, was surprised to see this situation (the people standing all around the plane) and he said to the 
people surrounding the plane: 'Hey brothers, what's this about?' I asked him to be patient.

At that moment a friend, who was from Java, came over and said: 'You get off the plane first.' He asked me: 'Are you going home?' I replied: 'Oh, no, in Jayapura there's a big meeting'. He said: 'Oh no, you'll stay here until you die'. We went into the MAF hangar. 'Now, take down some of your things. Take down the chair, the sewing machine, so the people here believe you are staying.'

My relationship with the community was really very close. They used to say: 'People like this man live to develop our country till they die, to die here'. Mr. Karma's interactions with the community had not been too close. As for me, every afternoon I would get into their stories using an interpreter. I said: 'If you see a place where there is still a lot of evil going on, you let me know, so we won't go there'. He said: 'No, bapak, here there's no danger. But if we go far away, that's where the danger is.' I had begun to learn the Dani language. Until finally I came across the place where HPB Gonsalvez had been; he had shot people there. Indeed I was a bit like that. When we were with people who were still primitive, we had to be brave. If we were not brave, they would step on us instead.

The incident with HPB Gonsalvez happened because indeed, in those days there were tribal wars over there. Orders had already been given prohibiting them from fighting tribal wars any more. They had to stop the wars. But it seemed that they still wanted to resist. Gonsalves was forced to shoot. The gunfire was so great that the situation calmed down again. I had heard the story from the people.

They thought firearms were like bamboo that was burned and then exploded. They said: 'That wasn't right'. Even though the gunfire worked to end the fight. So I mustered my courage and said: 'If you resist I'll put holes in your hands'. They said: 'Eee, we are afraid! Because before there was a white man who shot a gate and all of it, tjuuuus, was destroyed! The fence was blown into the sky.' 'Yes, the people who have come here have good intentions toward you. As I do.' That was it. Finally they said: 'Oh yes, it's true, we have to get along well again'.

My things were taken down from the plane and left there. I called over the interpreter and said: 'Let them know, my things are staying here. You should know that there is a big meeting for this nation happening in Jayapura. So do you understand? Later on a big meeting may 
also be held over here.' 'Oh yes, we believe you, because the chair and the machine have been taken down'. 'OK, Pablo, let's go!' Then we finally took flight and arrived in Jayapura. My wife and child had already gone down there earlier on. From Jayapura they had sent a letter to me through the MAF office in Sentani. They said: 'Don't you come yet'. So all that time I kept waiting in Bokondini because it was not safe yet in Jayapura.

Finally, we went. We got off in Sentani. It was hard to find a vehicle, because of the demonstration. I asked for a car to transport my goods to Dok IX. I had already sent a big tribal chief from Mamberamo to go down with my family to Jayapura. So as soon as I arrived, he was there to greet me: He said: 'Uuwe, you tricked me'. I asked: 'Why do you say that?' I was speaking with him in the Dani language. He said: 'Ann napur apmggo'. 'You are my son, you are a big man. Why did you go there, act as if you were a child? He thought I was a child when I first went to meet with him. He said: 'Now I know you are not a child. You are a great man. You are a great master.' I said: 'Oh, there is no need to think like that'. 'Well, what is the situation in my village? Is it still like this?' I answered: 'You go home, you have to stop the wars!' 'Aeeeee.... Ann napur ka taman.' Pray, child, that things can progress there the way they have here. He wanted his region to progress too.

I once walked for up to a week to get to his village. Well, all the people living in the village were his children. In that village there were no women or girls, all of them were men and boys. When sons grew up they married women from other villages, and they established their own settlements. On the mountain there, he said, there was copper that came out at about one meter deep. It was Mount Idenburg. He invited me to climb up, but I said no. The slopes of the Idenburg were very cold, I would not climb it.

The ministers living in the interior had worked hard. The bridge they had made to cross over to the other side of the gully was made of thick woven cords. When I crossed the bridge, I was afraid to look down because it was so deep. I walked carefully as I clutched the cords attached left and right. 


\section{NO OFFICIAL HOUSES YET}

When I arrived in Jayapura I reported to the Biro Pemerintahan (Administration Bureau), formerly called the Dienst van Binnenlandse Zaken, or Department of Home Affairs. I lived in Jayapura for a month while arranging my transfer to Serui. I asked whether housing was available for me in Serui, but they responded that there was none yet. Because of that, I went to the Administration Bureau. The head of the bureau was a Javanese. He kept asking me: 'Are you going to Serui or not?' I answered: 'Bapak, I have a family with me now. We have asked in Serui about housing for us, but there is no housing yet.' Now he asked again: 'Do you want to leave or not?' I replied: 'I am not leaving, Pak'. 'OK.' He told his deputy, Mr. Manggara, a relative of Mr. Boekorsjom: 'Manggara, find a table and chair for Saroy.' Then to me he said: 'Each morning I see you here!' I said: 'Ready!', using the military style of speaking. So, every morning I kept coming.

The administrative bureau head's name was Pak Hartono. He could also speak Dutch. It was not long before Faidiban came from Manokwari. $\mathrm{He}$ had been released from detention together with Pak Boekorsjom. He came to replace a Batak friend of mine who had to leave to attend studies at the Institut Ilmu Pemerintahan (IIP, Institute of Administrative Science) in Jakarta, like John Djopari. So Faidiban came to replace him. I kept working there until I had to go study at the APDN. Faidiban was recommended to become the regional secretary in Biak. Consequently, he moved to Biak. So at that time it was arranged with Faidiban, that later, after Faidiban was in Biak, he would arrange for me to follow him there. We asked in Biak: 'How about the problem of a house for Saroy?' But there was no answer. Pak Harto was forced to say: 'Alright, you just stay and work here!' So I kept working at the Biro Pemerintahan in Jayapura.

I kept on working there and there were continuous changes. Governor Frans Kaisiepo was replaced by Governor Acub Zainal, who was the commander of the Cendrawasih XVII military region at the time. He was the one who got Awom (Ferry Awom, the founder and leader of the OPM in 1965) to come out of the forests and give himself up in Manokwari. Acub Zainal said: 'Either you come down or I'll come up!' Then Awom was brought to Mamberamo and murdered there. The army deliberately brought naughty women on board the ship. Someone 
had already been prepared to kill him and throw him overboard. So indeed, the Indonesian government was in the wrong there. A man like that should have been protected. That way, Indonesia's name would have been enhanced.

\section{THE PROBLEM OF PARTITIONING ${ }^{2}$}

If we compare the system of government from the $1960 \mathrm{~s}$ and $70 \mathrm{~s}$ until the 90 s there certainly were changes here and there, but the government was really in the hands of the military. So development went smoothly because people were afraid of the army. But take a look at it now, in the reform period, since Gus Dur became president. Everything may vary. But in the Soeharto era it was different. The system of government was influenced by the military system.

Formerly, if an administrator with a Dutch education, like me, Wamafma, or Boekorsjom came late to the office, our superiors would ask: 'What time is it now? At ease. Come see me in a bit.' That was how it worked then.

But now it is no longer like that. As soon as you enter the office, an employee calls: 'Eh, please bring over that document. Call Ute over here! We have a meeting there later. For the next while if anyone wants to see me, say that I'm in a meeting.' There is no sense of responsibility. And it is like that every day. The administration is not well managed. Everything is chaotic.

Formerly, the initiative shown by civil servants was far better. Nowadays I see only people looking for money. People do not evaluate whether the work they have done is good or not. All they think about is: 'Well, how much money will I make'. Ah, they are just like shopkeepers. It cannot work like that.

Where does the money come from - if they calculate what they get aside from their base salaries? The money comes from projects. In the DPRD the spending budget is fixed. They debate how much money is to be spent for this year: how much money for projects, and how much money for the routine budget. The routine one is the normal budget,

\footnotetext{
2 Pemekaran, literally 'blossoming', is the Indonesian term used to refer to the policy of partitioning existing provinces/regencies into a greater number of provinces/regencies, and more generally, to the fragmentation of power ensuing from Reformasi and decentralization.
} 
including salaries, wages, honoraria and everything else. But with projects, it is another thing. Take, for example, a project worth one billion rupiah. If I am the person designated as the project leader, I have a right to receive ten percent of that billion. So 100 million rupiah is my portion as project leader.

That is the portion for the project leader. So every official tries to be the one appointed as project leader. The other day I was transferred from the Bureau of Administration to the Bureau of Material Supplies and Maintenance. This bureau is equivalent to the Centrale Bevoorrading Landsmagazijnen (CBL) in the Dutch period. Now it has been Indonesianized as a government agency. The former CBL was also government owned. So each residency had a branch. All goods were sent to the central CBL in Hollandia, which would then distribute them to all the regions.

The regions had to be accountable to the centre. But it is not that way today. Now it has become a bureau that functions independently. So, in fact, the Bureau of Supplies should be unified with the Bureau of Finance because it is concerned with money and goods.

If I look at the present system of government in this province up to now, if the province were to be divided into two provinces, that would be fine. Only the bureaucratic system should be changed. If it were truly a special autonomous region, it would be constructed as it was before in Dutch times, with eight offices or departments, namely: the Finance Department, Department of Economic Affairs, Department of Home Affairs, Department of Education and Cultural Affairs, Department of Health, Department of Agriculture and Fisheries, Department of Transport and Water, and Department of Public Works. That would be enough; there should not be too many agencies, which would be troublesome. It should be seen in terms of the size of the population of Papua, so that the division of work can be evenly distributed. And that could make the people prosperous. But if there are too many departments, then where do you bring the people from to work in them?

Just one province would be fine too. But if you want to ensure the welfare of all Papuans, only one more province should be added, that is it! It would be a hassle if there were three provinces. Has the central government given that any thought? Actually, they must reopen the pages on the history of this land. Before, in the time when the Dutch were here, everything ran well. But do not forget religion; religion is a must! Because 
what drives it all is a good spirit. Because if it is driven by an evil spirit, we all get confused. 